Convention DMS-ARC/CReA-Pat/2017-247 entre la Région Bruxelles-Capitale et le Centre de Recherches en Archéologie et Patrimoine de l'ULB : études archéopédologiques en Région de Bruxelles-Capitale

\title{
Micromorphological report of Tour Anneessens (BR081)
}

\author{
Arnald Puy
}

Centre de Recherches en Archéologie et Patrimoine, ULB

June 2018 
Arnald Puy

Centre de Recherches en Archéologie et Patrimoine (CReA-Patrimoine)

Université Libre de Bruxelles

Avenue F. Roosevelt, 50, CP133-01

1050 Bruxelles

E-mail: arnald.puy@gmail.com 


\section{Table of Contents}

1 Introduction $\quad 4$

2 Materials and methods $\quad 4$

3 Results $\quad 4$

$3.1 \quad$ Profile $\mathrm{PRO} 2 \ldots \ldots \ldots \ldots \ldots \ldots \ldots \ldots \ldots$

$3.1 .1 \quad$ Stratigraphic profile $\ldots \ldots \ldots \ldots \ldots \ldots \ldots$

3.1 .2 TS US $279-274-281 \ldots \ldots \ldots \ldots \ldots \ldots \ldots \ldots$

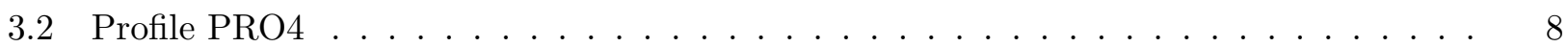

3.2 .1 Stratigraphic profile . . . . . . . . . . . . . . 8

3.2.2 TSs US CC1 379a, CC1 379a-328, CC1 322-328 and BB1 375-322 (framed in green in Figure 4$) \ldots \ldots \ldots \ldots$

3.2.3 TSs EE1 380-333, FF1 380-33, GG1 380-33, EE2 380, FF3 378, KK3 382 and JJ3 382 (framed in red in Figure 4$) \ldots \ldots$. . . . . . . . . . . . . 12

4 Discussion and conclusions $\quad 18$ 


\section{Introduction}

This report presents the micromorphological study of the soil blocks retrieved from a trench in the site of Tour Anneessens. Details on the topography, edaphology and general characteristics of the site can be found in Devos (2010) and Devos (2013a).

\section{Materials and methods}

The description of the thin sections (TS henceforth) followed the guidelines set forth in Stoops (2003). The interpretation of the micromorphological features is based on Stoops et al. (2010), Nicosia and Stoops (2017), MacKenzie et al. (2017) and Barker (2014). Photomicrographs have been taken under Plane Polarized Light (PPL) and Cross Polarized Light (XPL) using a Motic BA310Pol ${ }^{\circledR}$ trinocular microscope equipped with a 5 X Moticam ${ }^{\circledR}$.

\section{Results}

\subsection{Profile PRO2}

\subsubsection{Stratigraphic profile}

Figure 1 presents the stratigraphic profile of PRO2. In the field, the features of layer 274 (e.g. microlayering, phosphate/iron/manganese nodules) suggested its characterization as an ancient occupation surface. One undisturbed soil sample including layers 279, 274 and 281 was retrieved from the stratigraphic profile to test this hypothesis by means of soil micromorphology (Figure 1B).

\subsubsection{TS US 279-274-281}

Layer 279 is mostly a mineral layer formed by pebbles (c. 2 cm large) of sandstone and glauconite sandstone and subrounded, reworked soil fragments with a granostriated b-fabric (Figure 2A). One fragment of glauconite sandstone overlays a compact, horizontally-aligned, $1500 \mu \mathrm{m}$-thick clay-textured deposit with straight, planar voids. Pedofeatures concentrate in this clay-textured deposit and include common aggregate iron and manganese nodules, many of them horizontally aligned along planar voids, as well as limpid clay hypocoatings and dusty clay infillings (Figure 2B). The organic fraction in the layer is very scarce, amorphous and degraded. Voids include very few channels c. $2000 \mu \mathrm{m}$ large and $300 \mu \mathrm{m}$ wide, as well as few regular vughs. No anthropic inclusions have been observed.

$\underline{\text { Layer } 274}$ presents an intergrain microaggregate microstructure (single-spaced fine enaulic c/f related distribution). The mineral fraction consists of very dominant subangular and subrounded monocrystalline quartz grains, as well as common fragments of glauconite sandstone. A fragment of basalt was also identified (Figure 2C-D). The organic fraction is characterized by frequent plant 
a

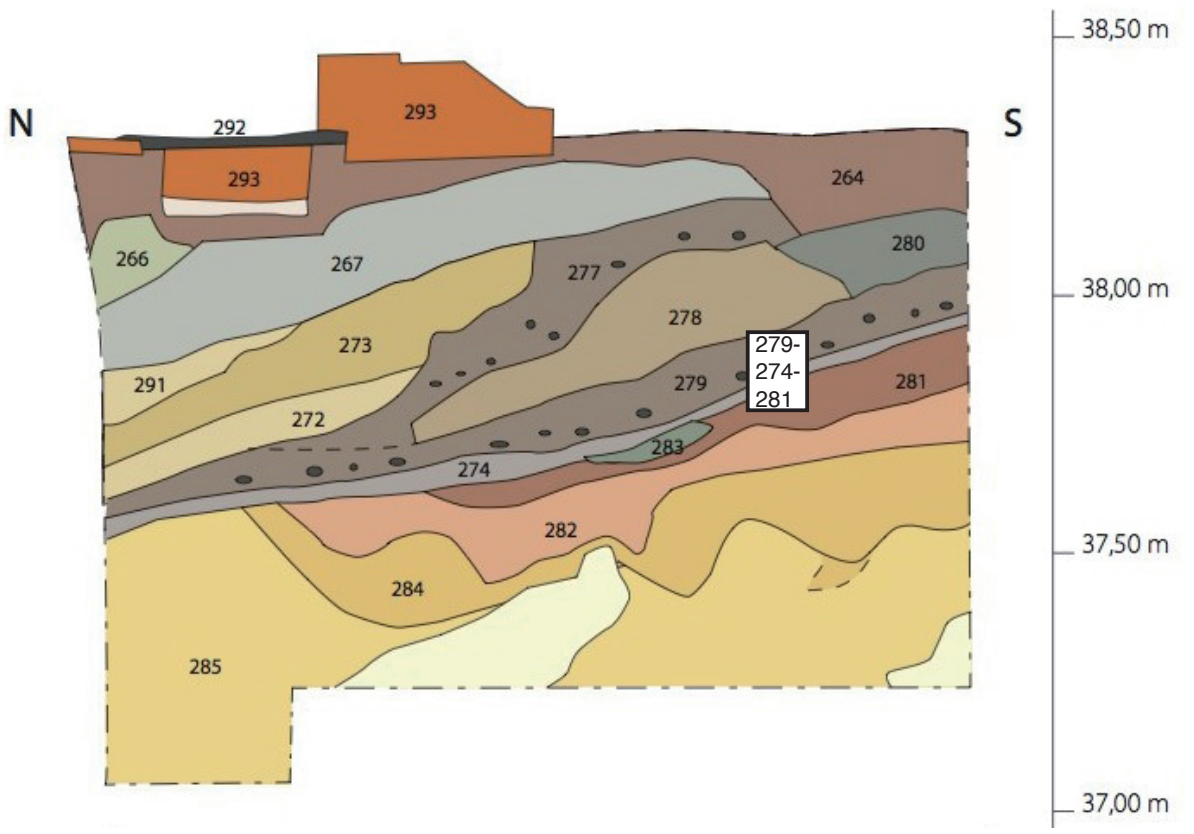

b

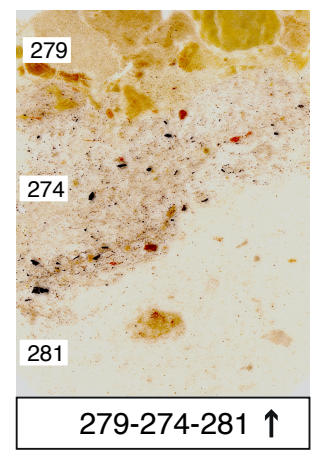

Figure 1: Profile PR02. a) Stratigraphic profile, adapted from Devos (2013a). The white square shows the position of the undisturbed soil block retrieved for micromorphological analysis. b) TS produced from the soil block shown in a) with the corresponding layers identified macromorphologically.

pseudomorphs (mostly horizontally aligned) and highly decomposed organic matter and organic punctuations, with some plant remains associated with fungal spores. Pedofeatures consist of moderately to strongly impregnated typic and aggregate iron nodules, iron infillings and iron coatings around quartz grains. Anthropic features include few compact, subrounded, unburned bones less than $1 \mathrm{~mm}$ large evenly dispersed throughout the layer (some with cracks and possible signs of splintering, as well as internal and external iron and manganese staining); charcoal up to $2000 \mu \mathrm{m}$ in length (Figure 2E-F); subrounded soil fragments showing reddening, possibly due to burning (Figure 3A); and phosphatic features (nodules and infillings, some associated with the degradation of bone tissues). There are also possible excrements characterized by a yellowish-brown, dirty phosphatic groundmass embedding plant pseudomorphs, aggregate iron nodules, bone fragments and chrysophycean stomatocysts (Figure 3B-D). Few dendritic phytoliths articulated in lines and bands and associated with plant pseudomorphs have been observed, as well as rare isolated blocky and elongated phytoliths (Figure $3 \mathrm{E}-\mathrm{F})$.

$\underline{\text { Layer } 281}$ has a single grain microstructure (coarse monic c/f related distribution), consisting of very dominant, well sorted angular and subangular monocrystalline quartz grains, mostly of very fine sand $($ c. $100 \mu \mathrm{m})$ texture. Some areas present also a concave gefuric c/f related distribution. Pedofeatures are uncommon and include iron infillings and secondary, typic iron nodules as well as clay coatings around quartz grains. 


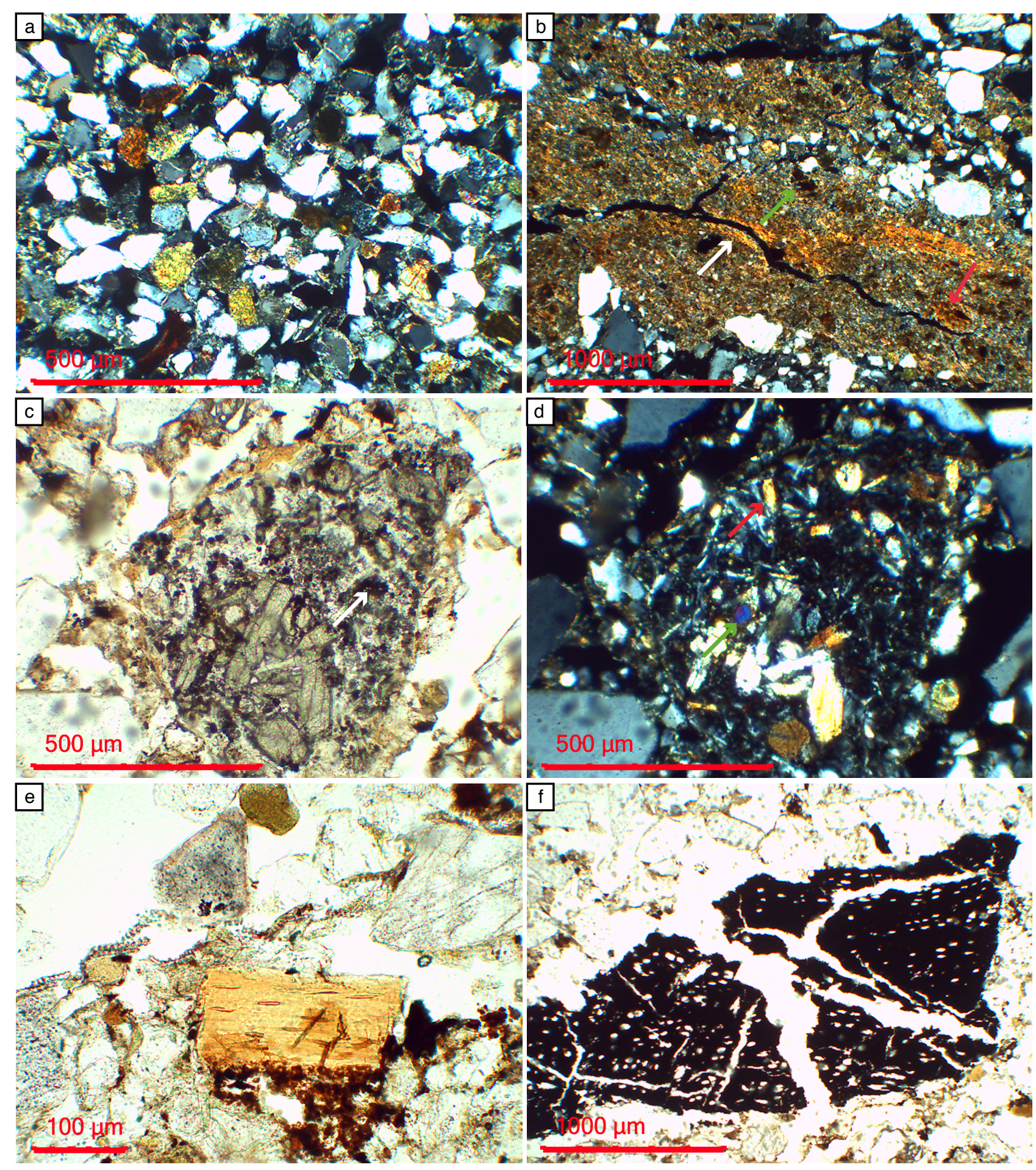

Figure 2: Microphotographs from PRO2, taken under plane polarized light (PPL) and cross-polarized light (XPL). a) Detail of a glauconite sandstone. Note the glaconite grains, showing second-order green to yellow colours (XPL). b) Clayed-textured deposit underlying a glauconite sandstone. Note the planar void, the limpid clay hypocoating (white arrow), and the iron (red arrow) and manganese (green arrow) aggregate nodules (XPL). c) Basalt. The white arrow points to magnetite (PPL). d) Same as c) but in XPL. The red arrow points to clynopryoxene and the blue arrow to olivine (XPL). e) Unburned bone. Note the oxide staining underneath the bone as well as the line of dendritic phytoliths above (PPL). f) Charcoal (PPL). 


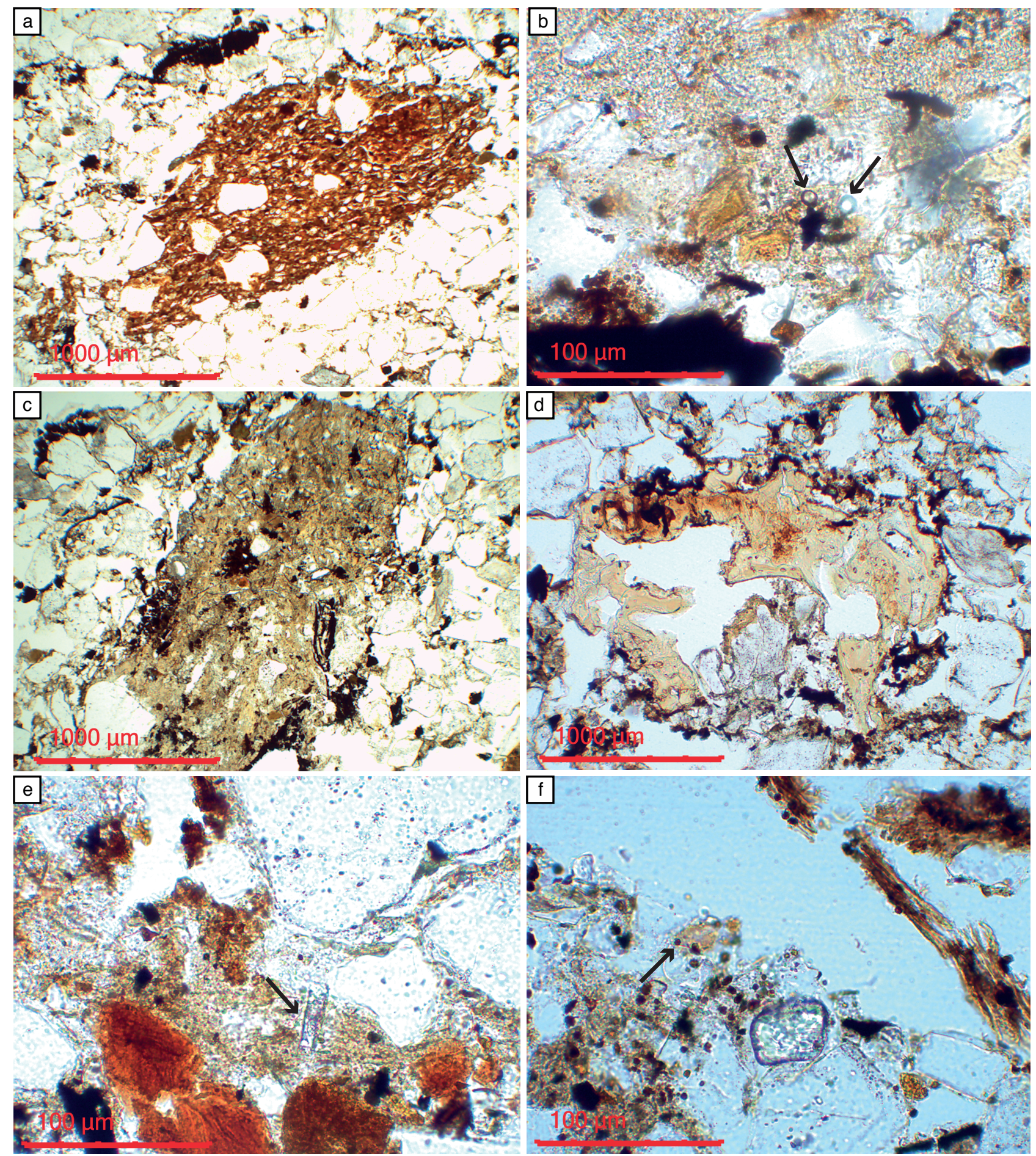

Figure 3: Microphotographs from PRO2, taken under plane polarized light (PPL) and cross-polarized light (XPL). a) Fragment of reddened soil, possibly burned (PPL). Chrysophycean stomatocysts (black arrows) in an excrement (PPL) c) Excrement. The phosphate groundmass is optically isotropic and includes cellulose fragments and charred plant remains (PPL). d) Excrement. Note the partially dissolved bone fragments in the phosphatized groundmass as well as the signs of oxidation (PPL). e Elongated phytolith (black arrow) (PPL). f) Blocky phytolith. The black arrow point towards fungal spores (PPL).) 


\section{$3.2 \quad$ Profile PRO4}

\subsubsection{Stratigraphic profile}

Figure 4 shows the stratigraphic profile of PR04. In the field, the features of layer 325 (e.g. microlayering, phosphate/iron/manganese nodules) also suggested its characterization as an ancient occupation surface. The stratigraphic sequence containing layers 325-324 was sampled to test this hypothesis by means of soil micromorphology. Four undisturbed soil blocks (framed in green in Figure 4) were collected to assess the transition from layer 325 to layer 322. Seven undisturbed soil blocks (framed in red in Figure 4) were retrieved to check whether layer 325 displayed spatial heterogeneity.

Different layers not identified in the field were macroscopically distinguishable in the TSs. These layers have been labelled with the number of their stratigraphic unit followed by a letter and, in case needed, by a letter and a number (Figure 4B). 
a
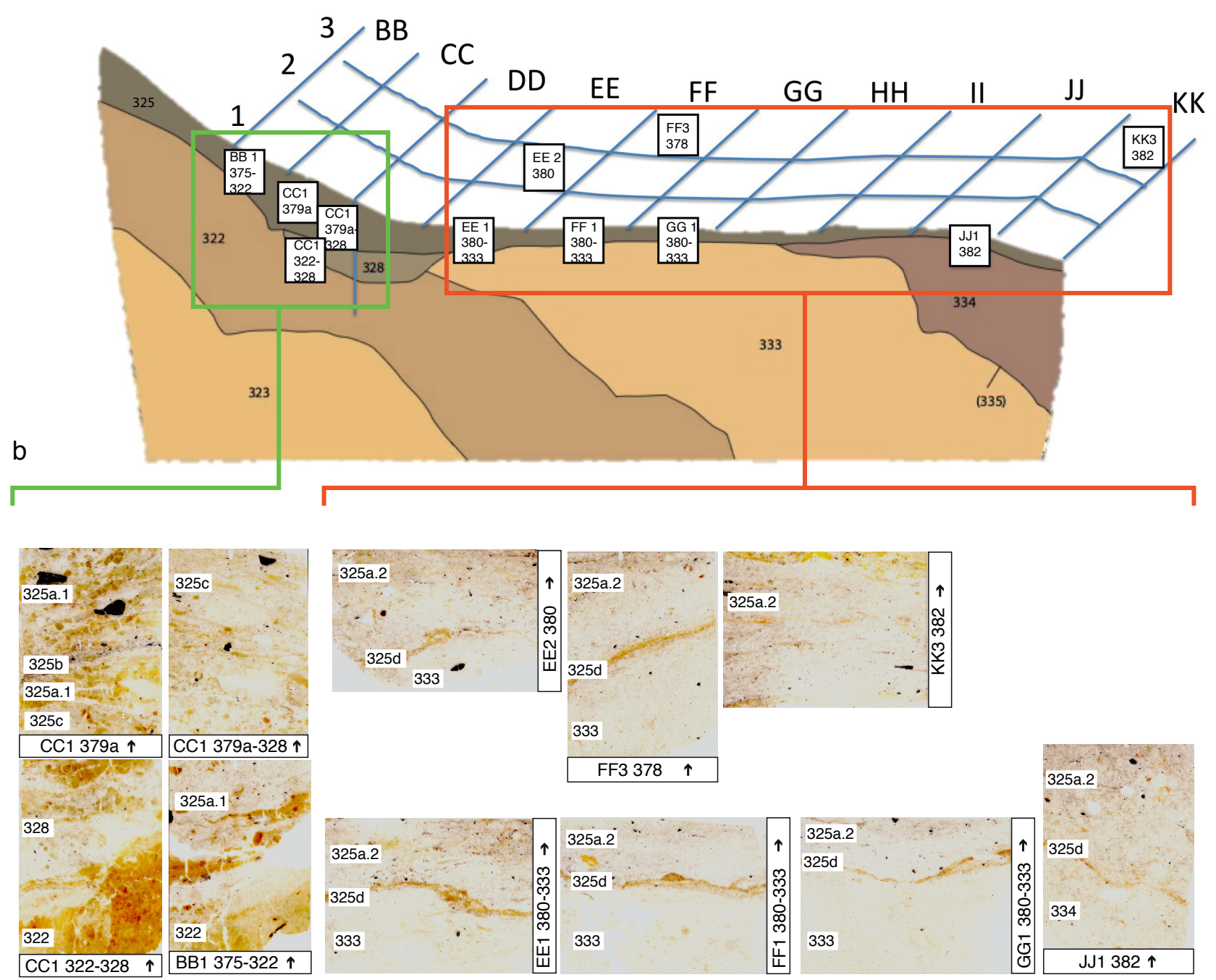

Figure 4: Profile PR04. a) Stratigraphic profile, adapted from Devos (2013a). The white square shows the position of the undisturbed soil block retrieved for micromorphological analysis. The green and red frames displays how the thin sections have been grouped for the micromorphological description (see sections 3.2.2 and 3.2.3. b) Thin section produced from the soil blocks shown in a) with the corresponding layers identified in the field.

\subsubsection{TSs US CC1 379a, CC1 379a-328, CC1 322-328 and BB1 375-322 (framed in green in Figure 4)}

Layer 325a.1 presents a moderately defined inclined bedding of mineral-rich layers (single grain microstructure, coarse monic c/f related distribution) and layers consisting of fine-textured, rounded and subrounded soil aggregates, mostly between 0.3 and $0.7 \mathrm{~cm}$ large (Figure $5 \mathrm{~A}$ ). The mineral fraction is well-sorted, presents a very fine sand texture (c. $100 \mu \mathrm{m}$ in diamater) and is characterized by very dominant subangular and subrounded monocrystalline quartz grains, frequent sandstone and glauconitic sandstones and very few mudstones. The soil aggregates embed some cellulose plant remains and display both a stipple-speckled and a granostriated b-fabric. The organic fraction is scarce; no organic punctuations have been observed, and few horizontally-aligned plant pseudomorphs appear 
in some parts of the layer, sometimes associated with radiating fan-like impregnations of phosphatic, brownish material. Iron pedofeatures concentrate in the soil aggregates and include moderately to strongly impregnated aggregated and typical nodules, as well as iron hypocoatings. Some areas of the layer display also clean clay coatings around quartz grains and clay infilling of voids. As for anthropic inclusions, the layer presents three charcoals c. $1 \mathrm{~cm}$ large and $0.5 \mathrm{~cm}$ wide, common smaller charcoals and one single fragment of unburned, subrounded, compact bone. No other anthropic features were observed.

Layer 325b is a $1 \mathrm{~cm}$ thick, loosely packed, well-defined inclined deposit (single to double spaced equal enaulic c/f related distribution) characterized by very dominant charcoals, charred plant remains and amorphous dark organic material, dominant small $(>150 \mu \mathrm{m})$ subrounded compact calcined and unburned bone fragments, as well as horizontally aligned plant pseudomorphs associated with phosphatic impregnations (Figure 5B). No reddening of the groundmass nor ashes has been observed, and only very few phytoliths, mostly dendritic and articulated and associated to plant remains, have been identified. Few reworked soil fragments containing quartz and glauconite grains are also present.

Layer 325c presents the same bedding features as layer 325a.1, although more defined and without as many soil aggregates. It also shows more horizontally-oriented plant pseudomorphs. Fragments of calcareous mortar dissolved in the groundmass have been observed (Figure 5C).

$\underline{\text { Layer } 328}$ is mainly a mineral layer formed of dominant monocrystalline quartz grains of two different fractions, c. $180 \mu \mathrm{m}$ and c. $60 \mu \mathrm{m}$, and inclusions of soil aggregates, some with a granostriated b-fabric. Few glauconite grains are also present. A moderately impregnated, horizontally-oriented phosphatic crust of c. $2 \mathrm{~cm}$ long and $1 \mathrm{~mm}$ thick, with inclusions of plant remains, has been identified in the lowermost section of the layer (Figure 5D). Few well-impregnated typic phosphate nodules, as well as few charcoals, are visible in the groundmass.

Layer 322 presents a subangular blocky microstructure, with either an open or close porphyric $\mathrm{c} / \mathrm{f}$ related microstructure. It is formed by a mixture of grains (dominant quartz and few glauconite) c. $70 \mu \mathrm{m}$ large and clayish, moderately to highly separated, partially accommodated blocky peds less than $400 \mu \mathrm{m}$ in diameter. The peds present a crystallitic or a parallel-striated b-fabric. Pedofeatures are characterized by common iron hypocoatings, moderately to strongly impregnated aggregate and typic iron nodules, some with pyrite framboids, and few iron depletion pedofeatures (Figure 5E-F). The organic fraction consists mainly of very few amorphous, black material. No anthropic inclusions have been observed. 

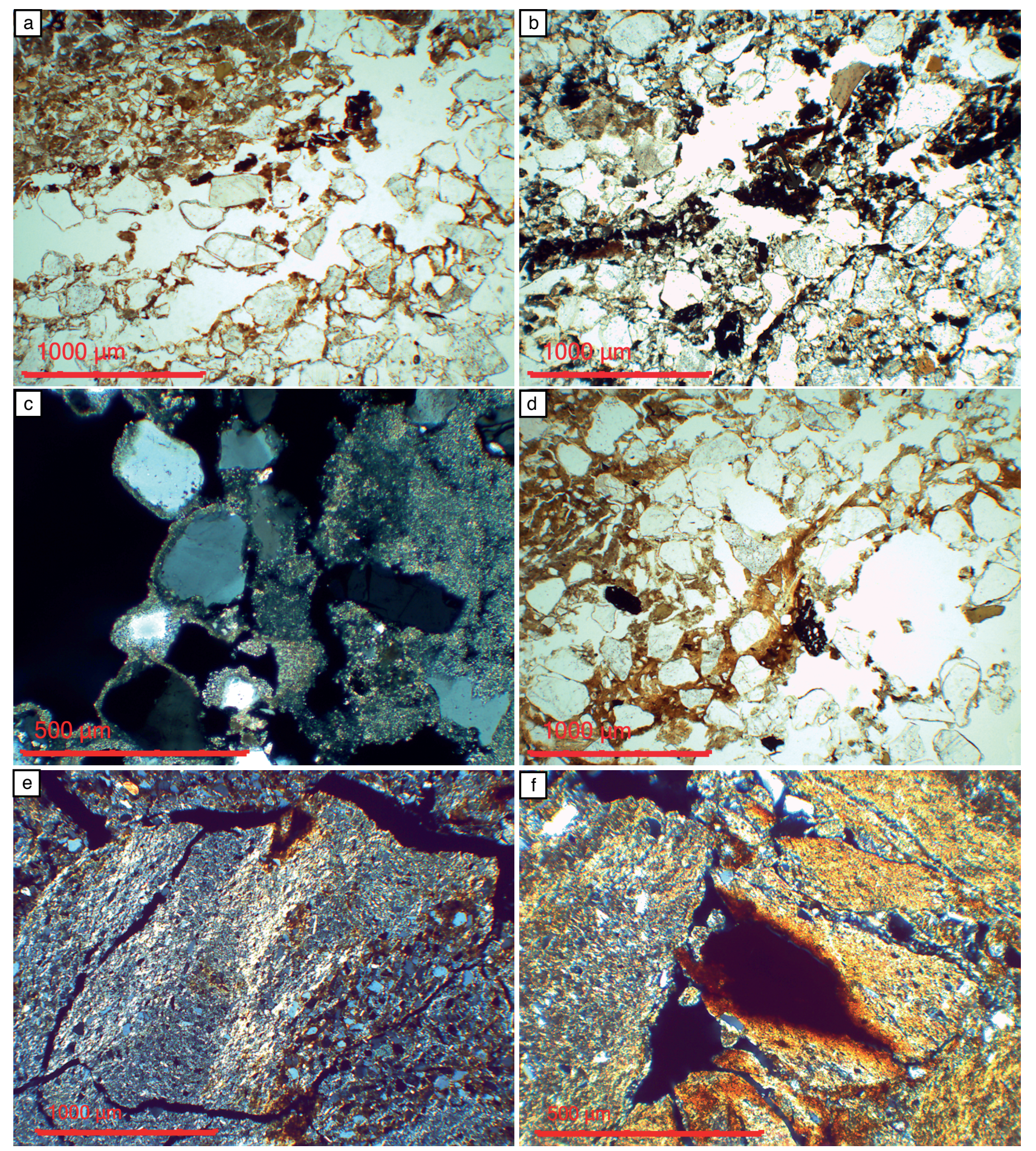

Figure 5: Microphotographs from PRO4, taken under plane polarized light (PPL) and cross-polarized light (XPL). a) Boundary between a soil aggregate (top-left side) and a mineral-rich unit (bottom-right side) (PPL). b) Layer rich in charcoals and burned plant fragments. Note the calcined bone to the top-right side of the frame (PPL). c) Dissolved mortar. Note the micritic calcitic crystals coating the quartz grains (XPL). d) Phosphatic crust (PPL). e) Depletion iron pedofeature. Note the white colour of the groundmass due to the mobilization of iron (XPL). f) Iron hypocoating (XPL). 


\subsubsection{TSs EE1 380-333, FF1 380-33, GG1 380-33, EE2 380, FF3 378, KK3 382 and JJ3 382 (framed in red in Figure 4)}

Seven TSs were collected from the westernmost part of PRO4 to check whether layer 325 presents spatial heterogeneity (Figure 4).

Layer 325a.2 presents mostly a bridged/pellicular grain microstructure (chitonic/concave gefuric $\mathrm{c} / \mathrm{f}$ related distribution) in TS EE1, and a dominant single grain microstructure (coarse monic c/f related distribution) in the rest. The layer also includes many soil aggregates characterized by a granostriated b-fabric, often embedding sponge spicules. The mineral fraction is moderately to well sorted and consists of very dominant monocrystalline, subrounded and subangular quartz grains, common fragments of sandstone, frequent glauconite grains and very few muscovite grains. The dominant grain size is $20 \mu \mathrm{m}-40 \mu \mathrm{m}$ in diameter, although few smaller grains are also present $(3 \mu \mathrm{m}-10 \mu \mathrm{m}$ in diameter). The organic fraction is characterized by organic punctuations and decomposed plant remains, partially impregnated with iron and phosphates and mostly horizontally aligned throughout the layer (Figure 6A). Pedofeatures include frequent orthic phosphate nodules with very few vivianite crystal intergrowths (Figure 6B), dusty clay coatings around quartz grains, and frequent typic and aggregate iron nodules. Few chrysophycean stomatocysts have also been identified.

Table 1 presents the abundance of anthropic inclusions in layer 325a.2. Unburned and partially calcined spongy, subrounded bones have been observed mostly in TS EE1 and FF1 (Figure 6C), as well as fish scales with denticulated edges in TSs EE1 and EE2 (Figure 6D). Fragments of mortar and pottery concentrate mainly to the $\mathrm{W}$ of the stratigraphic profile, in TSs EE2, FF3, JJ1 and KK3. The mortar shows features of calcareous mortar, characterized by a crystallitic b-fabric and inclusions of subangular quartz grains (mostly monocrystalline), glauconite grains and microfossils. The pottery fragments present a dark-red color (PPL), and sometimes a coat of fine, dirty silt material (Figure 6E-F). Fragments of charcoal ranging from submillimetric to $700 \mu \mathrm{m}$ are common in the layer, and many appear impregnated in phosphate. Phytoliths are present in all TSs and especially abundant in TS KK3. There are many articulated, dendritic and elongated phytoliths within parallel bands of horizontally-oriented plant remains, as well as non-articulated phytoliths infilling channels and voids (Figure 7A-B, F). 


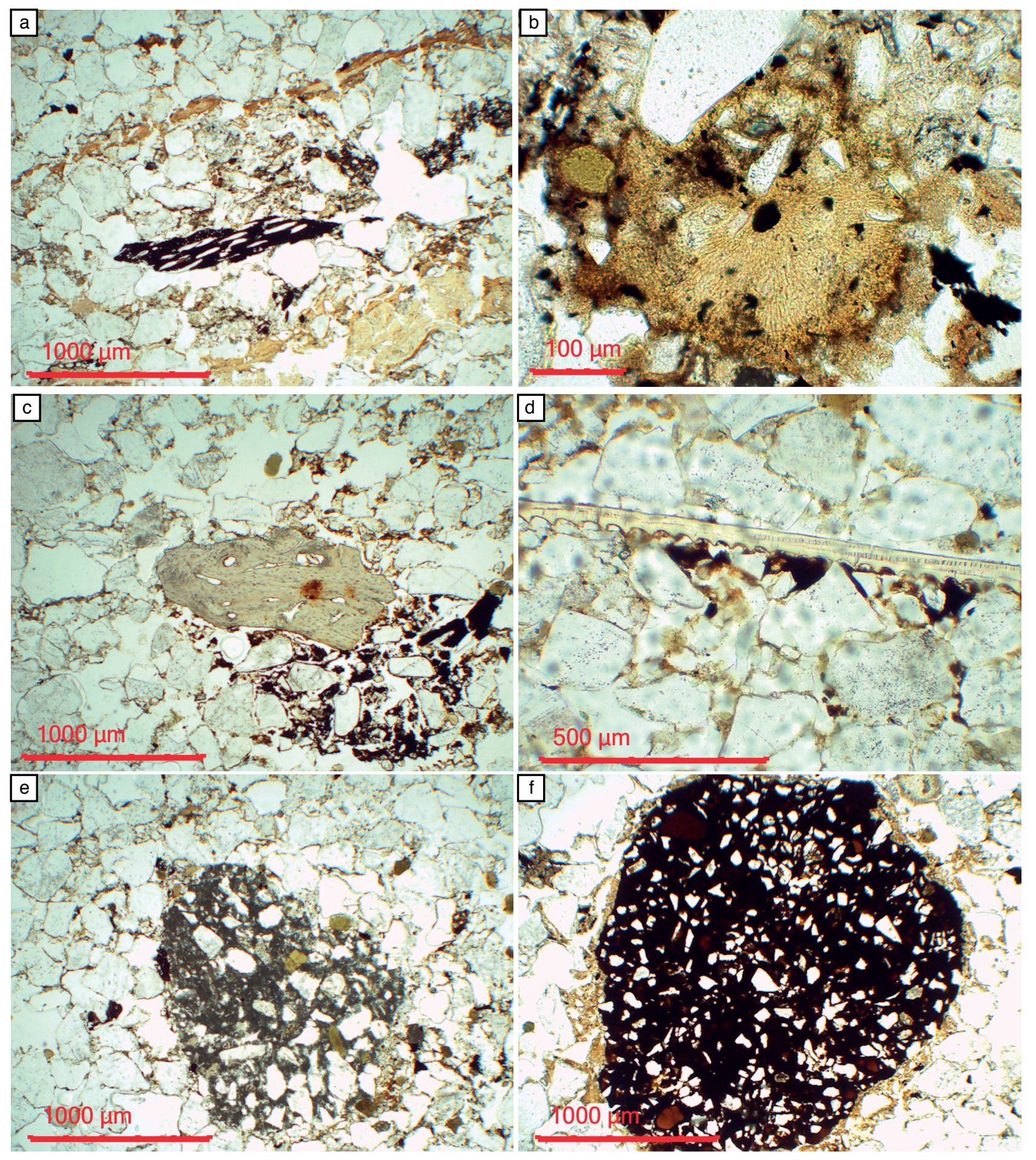

Figure 6: Microphotographs from PRO4, taken under plane polarized light (PPL) and cross-polarized light (XPL). a) Horizonation of plant pseudomorphs and charcoal fragments. Note the phosphate-replaced plant tissue below (PPL). b) Radiating phosphate nodule with a single vivianite crystal intergrowth (first-order green) (PPL). c) Bone fragment, possibly calcined (PPL). d) Fish scale (PPL). e) Calcareous mortar with inclusions of glauconite grains (PPL). f) Fragment of rounded pottery. Note the coat of silt material (PPL). 


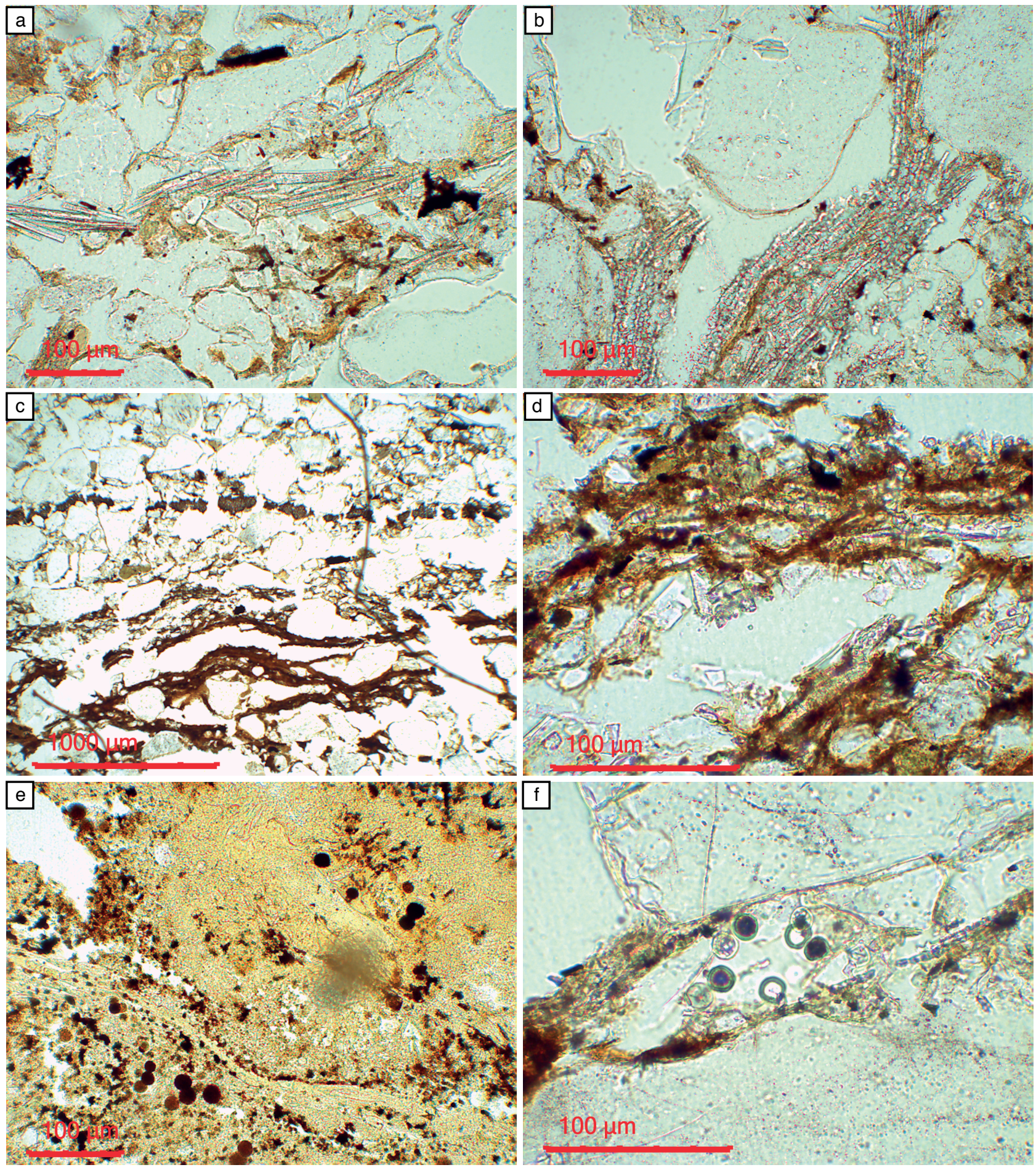

Figure 7: Microphotographs from PRO4, taken under plane polarized light (PPL) and cross-polarized light (XPL). a) Elongated phytoliths (PPL) b) Dendritic phytoliths (PPL). c) Horizontal layering of plant fibres. Note the internal rim, formed of thicker fibres, and the outer rim, which includes unarticulated phytoliths (PPL). d) Close up of the phytoliths detected in c). Note the presence of elongated, saddle, rondel and dendritic phytoliths (PPL). e) Phosphatic impregnation, probably an excrement. Note the pyrite framboids (black spheres) as well as the funghal spores (red, semitransparent spheres) (PPL). f) Line of dendritic phytoliths in a channel void. The spheres are reasonably an artefact derived from the resin used during the impregnation of the soil blocks before thin section production (PPL).

Layer 325a.2 also includes, in some sections, other two well-differentiated features:

- TSs EE2 and FF3 present, on the topmost part of the slide, a partially truncated, highly-porous 
Table 1: Abundance of anthropic inclusions in layer $325 \mathrm{a} .2:^{*}=$ few ${ }^{* *}=$ common; $* * *=$ dominant.

\begin{tabular}{lccccccc}
\hline Anthropic inclusion & EE1 & FF1 & GG1 & EE2 & FF3 & JJ1 & KK3 \\
\hline Unburned bones & $*$ & $* *$ & & $*$ & & & $* *$ \\
Calcined bones & $*$ & $*$ & & & & & $*$ \\
Pottery sherds & & & & $* *$ & $* *$ & $*$ & $*$ \\
Mortar & & & & $*$ & $*$ & & \\
Phytoliths & $*$ & $*$ & $*$ & $* *$ & $* *$ & $*$ & $* * *$ \\
Fish scales & $*$ & & & $*$ & & & \\
Excrements & $*$ & $*$ & $*$ & $* *$ & $* *$ & $* *$ & $* * *$ \\
Charcoals & $* * *$ & $* * *$ & $* *$ & $* *$ & $* * *$ & $* *$ & $* *$ \\
Seed exocarps & $*$ & & & & & & \\
\hline
\end{tabular}

(40-50\%), c. $4 \mathrm{~mm}$ thick layer with two rims: the inner one shows an orange to brown-orange color (PPL) and is characterized by an horizontal layering of long (c. $1 \mathrm{~cm}$ large) and relatively thick $(150 \mu \mathrm{m})$ plant fibres, partially phosphatized and with organic matter punctuations. The outern zone is brown dark (PPL) and consists of several unarticulated phytoliths (dendritic, saddle and smooth elongate), mixed with horizontally oriented, thinner (c. $50 \mu \mathrm{m})$ plant tissues. The layer also includes small fragments of quartz and silt material as well as plant cellulose (Figure 7C-D). No calcium oxalate crystals or dung spherulites have been observed.

- TS KK3, also on the topmost part of the slide, shows a yellowish-coloured, $4 \mathrm{~cm}$-thick layer characterized by strongly impregnated phosphatic features, quartz grains, highly decomposed organic matter, horizontally-aligned plant remains, charcoals and excrements. The latter sometimes include spores and pyrite framboids (Figure 7E).

Layer 325d is a dark yellow to orange (PPL), c. $500 \mu \mathrm{m}-100 \mu \mathrm{m}$-thick layer of phosphates, excrements and horizontally-aligned, moderately well-preserved plant remains, with fragments of cellulose and inclusions of minerals with the same features and abundance as in layer 325a.2. It shows an undifferentiated b-fabric under XPL, although some areas also display a crystallitic or granostriated b-fabric due to the inclusion of soil fragments (Figure 8A-C). The layer shows distinct degrees of phosphatic impregnation and continuity depending on the TS: in TSs EE1, FF1 and GG1 it appears as a continuous, slightly weavy layer, with sharp boundaries and strongly impregnating the groundmass. In TSs EE2, however, it is partially truncated; in TS JJ1 it does not impregnate as much the groundmass, and in TS KK3 the layer is not visible anymore. Under fluorescent light the phosphatic crust appears autofluorescent, pointing towards hydroxyapatite (Devos, personal communication). Overall, pedofeatures include common typical and aggregate iron and manganese nodules, moderately to strongly impregnating the groundmass, as well as iron quasicoatings around channel voids. 


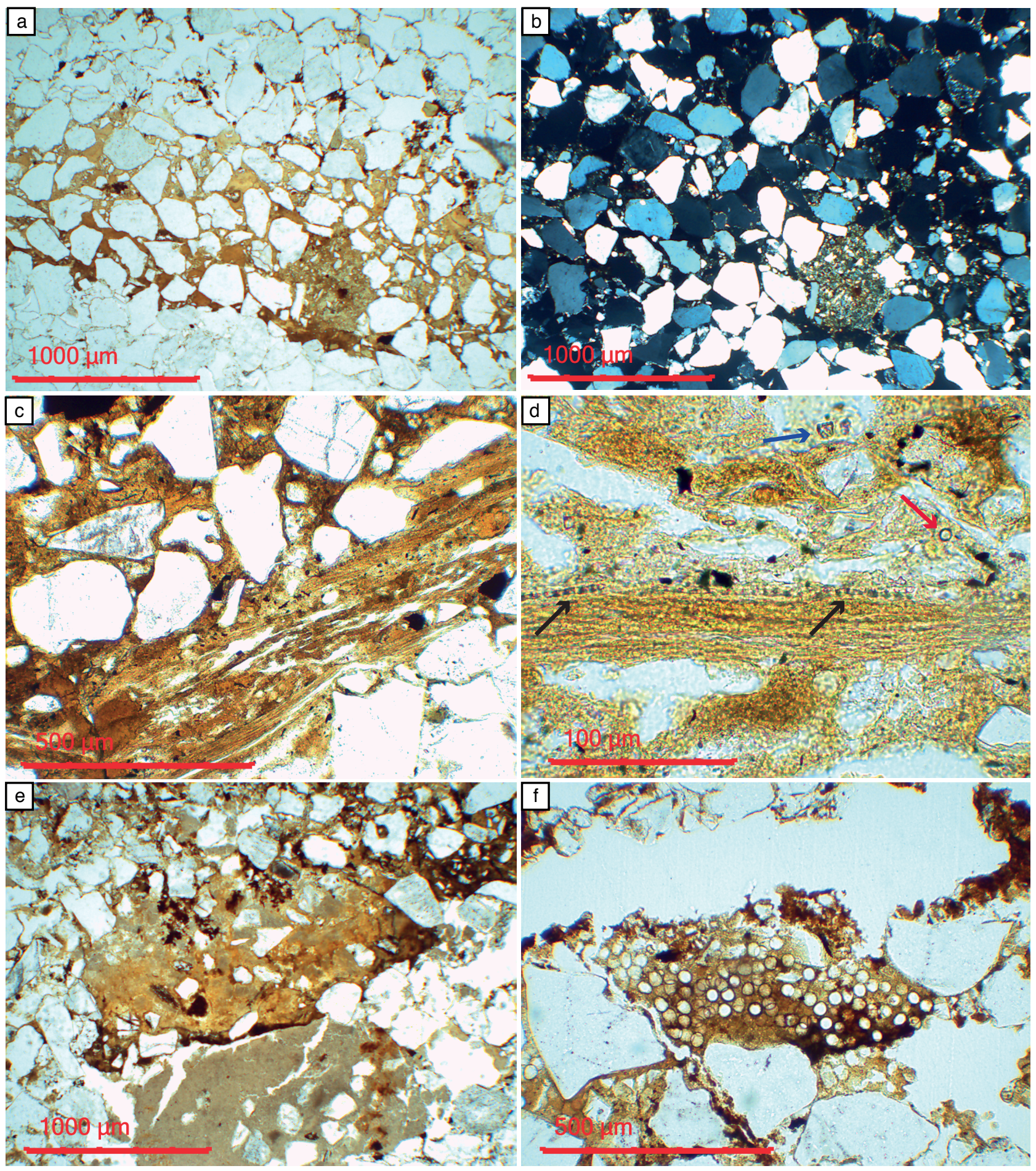

Figure 8: Microphotographs from PRO4, taken under plane polarized light (PPL) and cross-polarized light (XPL). a) Phosphatic crust (PPL). b) Same as a) but in cross-polarized light. Note the isotropy of the phosphatic crust (XPL) and the crystallitic b-fabric of the soil aggregate (XPL). c) Phosphatized plant remains (PPL). d) Band of phytoliths in a plant organ (black arrows); Chrysophycean stomatocyst (red arrow); and triangular/blocky phytolith (blue arrow) (PPL). e) Fragment of mortar (PPL). f) Possible fungal sclerotia (PPL).

Table 2 summarises the abundance of anthropic inclusions in layer 2. Compared to layer 1, layer 2 shows much less diversity. Most features concentrate in TSs EE1, GG1, FF1, EE2 and FF3. The most relevant characteristic is the presence of common articulated phytoliths in parallel bands along plant remains, as well as fragments of calcareous mortar in layer EE2, partially dissolved within the 
layer (Figure 8D-F).

Table 2: Abundance of anthropic inclusions in layer $2:{ }^{*}=$ few; $* *=$ common; $* * *=$ dominant.

\begin{tabular}{lccccccc}
\hline Anthropic inclusion & EE1 & FF1 & GG1 & EE2 & FF3 & JJ1 & KK3 \\
\hline Unburned bones & & $* *$ & & & & & \\
Calcined bones & & & & & & & \\
Pottery sherds & & & & & & & \\
Mortar & & & & $* *$ & & & \\
Phytoliths & $* *$ & $* *$ & $* *$ & $* *$ & $* *$ & $*$ & \\
Fish scales & & & & & & & \\
Excrements & & & & & & & \\
Charcoals & $*$ & $*$ & $*$ & $*$ & & & \\
Seed exocarps & & $*$ & & & & & \\
\hline
\end{tabular}

Layers 333 and 334 show mostly a single grain microstructure (coarse monic c/f related distribution), characterized by well-sorted, very dominant quartz grains and frequent glauconite grains. TSs FF3, JJ1 and KK3 also present some areas with an intergrain microstructure (single-spaced fine enaulic), with the fine material consisting of dirtly silt and clay. The very few inclusions of soil material present a granostriated b-fabric. No anthropic features or pedofeatures have been observed besides very rare fragments of charcoals and very few aggregate and typical iron and phosphate nodules moderately to strongly impregnating the groundmass.
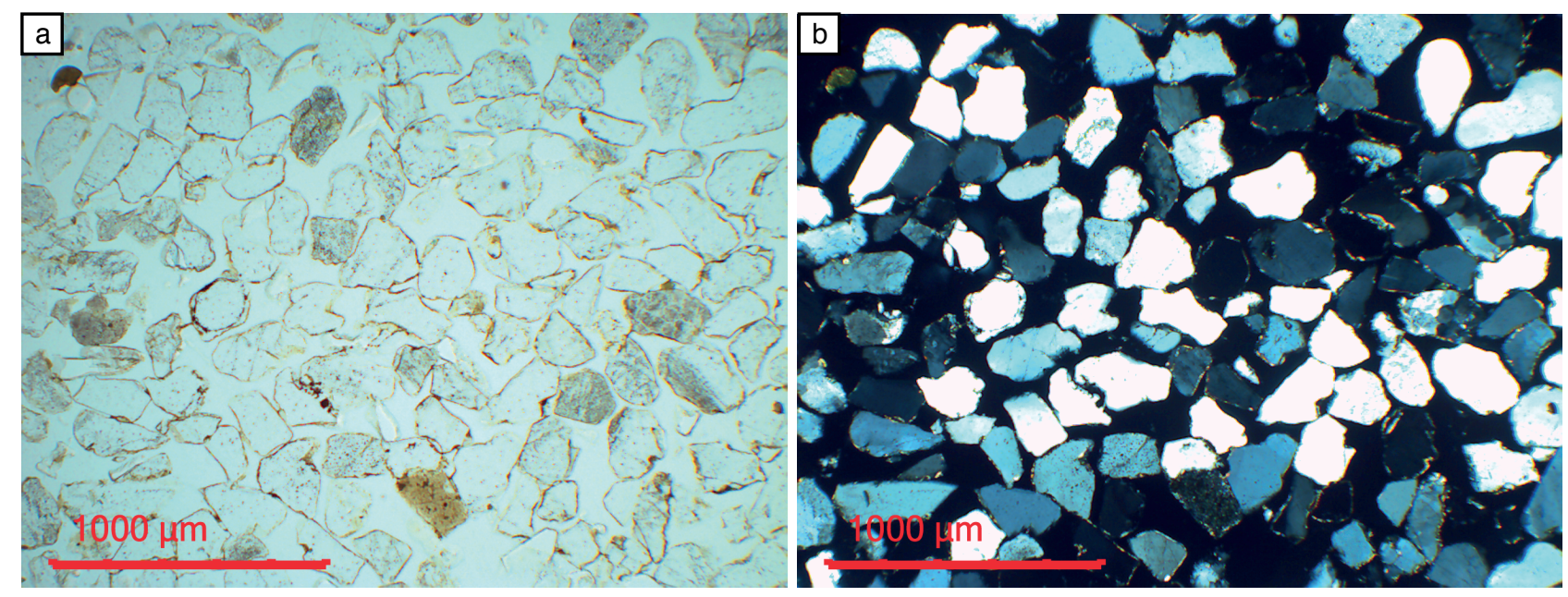

Figure 9: Microphotographs from PRO4, taken under plane polarized light (PPL) and cross-polarized light (XPL). a) Single grain microstructure (PPL). b) Same as a) but in XPL. 


\section{Discussion and conclusions}

The micromorphological features observed in the TSs point towards the identification of layers 274 and 325 as a stable floor deposit overlying silty-clay deposits (layer 322) and tertiary sands (layers 333 and 334). This is suggested by the presence of several layers of bedded, phosphate-replaced plant pseudomorphs with bands of dendritic phytoliths, excrements and an ubiquitous illuviated phosphatic crust that extends all over the sampled surface, especially between squares EE and GG (Figure 4A). The horizonation of plant remains likely results from the trampling of grasses or straw by animals or human traffic, a process that might also explain the formation of organic punctuations or microcharcoal through compression and rupture of charred materials. The ubiquitous presence of bands of dendritic phytoliths in plant remains is consistent with the characterization of layers 274 and 325 as a floor, as such predominant orientation can only be explained if the original plant material lied on a surface (Devos 2013b).

The phosphatic crust (layer 325d) shows the presence of hydroxyapatite $\left[\mathrm{Ca}_{5}\left(\mathrm{PO}_{4}\right)_{3}(\mathrm{OH})\right]$ and likely reflects the translocation of phosphates from decomposed plant remains, excrements and urine. Macphail et al. (2004) observed that the formation of calcium-phosphate crusts is due to short-lived anaerobic conditions induced by poor drainage of liquid waste produced by stable animals. Temporary waterlogged conditions during the formation of layer 325d are indeed inferred from the presence of pyrite framboids $\left(\mathrm{FeS}_{2}\right)$ in some excrements. As for urine, it contains nitrogen-rich urea $(2 \%)$, ammonia $(0.05 \%)$, uric acid $(0.03 \%)$ and $2 \%$ of dissolved salts (Milek 2012). Nitrogen enrichment due to urines and excrements might explain the growth of fungus and the presence of fungal spores in some phosphatic impregnations, such as those in Figure 7E. Fungal spores can also directly enter the archaeological record embedded in excrements of animals that grub and root for food, e.g. wild boars or pigs (Brönnimann et al. 2017).

Although the preserved faecal remains do not allow to unequivocally infer which animals were penned, some observations can be made. Firstly, the identification of rare excrements containing bone fragments (Figure 3D) points towards omnivore/carnivore animals (ibid.). Secondly, the presence of burned and unburned bone fragments, charcoal, fish scales or seeds mixed up in layer 325 suggests domestic food waste as a possible source of food for the animals. Thirdly, and despite being one of the main hallmarks for the identification of enclosures containing herbivore animals, spherulites [e.g. calcium carbonate nodules $5-15 \mu \mathrm{m}$ in size produced in the digestive tract of herbivore animals and usually found in dung deposits (Canti and Brochier 2017)] have not been identified. This might be explained by either their dissolution due to water through-flow and predominance of acid conditions or their effective absence from the archaeological record.

Finally, although it seems that the anthropic inclusions are irregularly distributed within layer 325 (see Table 1), the available data does not allow to spatially differentiate activity areas in the 
floor. However, it is possible to establish a rough delimitation of the main focus of animal activity based on the degree of impregnation of the phosphatic crust. On these grounds, animal activity would concentrate between square grid EE and GG, and decrease in intensity to the W and to the E. Further tests aiming at specifying the nature of the stable floor should therefore focus on bulk samples collected from this area. Possible venues of inquiry include:

- Phytolith analysis to identify the plant remains in the stable (Piperno 1988).

- Steroid biomarker analysis for the identification of faecal remains. Steroids are not prone to leaching but bind to the soil matrix, and can be used to distinguish between hervibore (horse, goat, sheep/cattle), pig and human faecal matter (Prost et al. 2017).

- Fourier-Transform Infrarred Spectroscopy (FTIR) to identify (phosphate) minerals and precise the formation process of the phosphatic crust (Weiner 2010). 


\section{References}

Barker, A.J. (2014). A Key for Identification of Rock-forming Minerals in Thin-Section. Leiden: CRC Press, Taylor \& Francis.

Brönnimann, D., C. Pümpin, K. Ismail-Meyer, P. Rentzel, and N. Égüez (2017). "Excrements of omnivores and carnivores". Archaeological Soil and Sediment Micromorphology. Chichester, UK: John Wiley \& Sons, Ltd, pp. 67-81. DOI: 10.1002/9781118941065.ch7.

Canti, M.G. and J.É. Brochier (2017). "Faecal spherulites". Archaeological Soil and Sediment Micromorphology. Ed. by C. Nicosia and G. Stoops. Chichester: Wiley-Blackwell.

Devos, Y. (2010). Étude archéopédologique des fouilles du site de la Tour Anneessens (Br 081). Tech. rep. Brussels: Centre de Recherches en Archéologie et Patrimoine, Université Libre de Bruxelles.

- (2013a). Etude archéopédologique des fouilles du site de la "Tour Anneesens", campagne 2011. Rapport de terrain. Tech. rep. Brussels: Centre de Recherches en Archéologie et Patrimoine, Université Libre de Bruxelles.

- (2013b). Etude Archéopédologique des Fouilles du Site "Hof ter Coigne" à Watermael-Boitfort (WB001). Rapport de Terrain (2e campagne). Tech. rep. Bruxelles: Centre de Recherches en Archéologie et Patrimoine, Université Libre de Bruxelles, pp. 1-12.

MacKenzie, W.S., A.E. Adams, and K.H. Brodie (2017). Rocks and Minerals in Thin Section. 2nd. London: CRC Press, Taylor \& Francis.

Macphail, R. I., G. M. Cruise, M. J. Allen, J. Linderholm, and P. Reynolds (2004). "Archaeological soil and pollen analysis of experimental floor deposits; with special reference to Butser Ancient Farm, Hampshire, UK". Journal of Archaeological Science 31.8, pp. 175-191. DOI: 10.1016/j . jas.2003.07.005.

Milek, K. (2012). "The roles of pit houses and gendered spaces on Viking-Age farmsteads in Iceland". Medieval Archaeology 56.1, pp. 85-130. DOI: 10.1179/0076609712Z.0000000004.

Nicosia, C. and G. Stoops, eds. (2017). Archaeological Soil and Sediment Micromorphology. Chichester, UK: John Wiley \& Sons, Ltd. DOI: 10.1002/9781118941065.

Piperno, D. (1988). Phytolith Analysis: an Archaeological and Geological Perspective. San Diego: Academic Press.

Prost, K., J. J. Birk, E. Lehndorff, R. Gerlach, and W. Amelung (2017). "Steroid biomarkers revisited - Improved source identification of faecal remains in archaeological soil material". PLoS ONE 12.1, pp. 1-30. DOI: 10.1371/journal. pone.0164882.

Stoops, G. (2003). Guidelines for Analysis and Description of Soil and Regolith Thin Sections. Madison: Soil Society of America, Inc.

Stoops, G., V. Marcelino, and F. Mees, eds. (2010). Interpretation of Micromorphological Features of Soils and Regoliths. Amsterdam: Elsevier. 
Weiner, S. (2010). Microarchaeology. Beyond the Visible Archaeological Record. Cambridge: Cambridge University Press. 